\title{
Stability of space use in Svalbard coastal female polar bears: intra-individual variability and influence of kinship
}

\author{
Clément Brun, ${ }^{1,2}$ Marie-Anne Blanchet, ${ }^{1,3}$ Rolf A. Ims ${ }^{2}$ \& Jon Aars ${ }^{1}$ \\ ${ }^{1}$ Norwegian Polar Institute, Fram Centre, Tromsø, Norway \\ 2Department of Arctic and Marine Biology, UiT The Arctic University of Norway, Tromsø, Norway \\ ${ }^{3}$ Norwegian College of Fishery Science, UiT The Arctic University of Norway, Tromsø, Norway
}

\begin{abstract}
Philopatry influences animal distribution and can lead to a kinship-based spatial structure, where proximity and relatedness are tightly linked. In the Barents Sea region, polar bears (Ursus maritimus) of the coastal ecotype remain yearround within the Svalbard archipelago. This coastal strategy is thought to be stable across years; however, little is known about the intra-individual variability in site fidelity or the influence of kinship on space use. Using high-resolution GPS telemetry, we looked at multi-year philopatry among 17 coastal female polar bears over eight years (2011-19) and investigated whether it is linked to the females' degree of kinship. Individuals showed a stable space use in both consecutive and non-consecutive years. Yearly individual home ranges (HRs) overlapped, on average, by 44\% (range: 9-96\%), and their centroids were, on average, $15 \mathrm{~km}$ (range: 2-63 km) apart. The space use of related females revealed a year-round strong female kin structure. Annual HRs of related females overlapped, on average, by $24 \%$ (range: 0-66\%), and their centroids were, on average, $18 \mathrm{~km}$ (range: $2-52 \mathrm{~km}$ ) apart. In contrast, non-related females had much larger distances between centroids (average: $160 \mathrm{~km}$, range: 59-283 km). Additionally, females showed a great site fidelity in all seasons: individual seasonal HR centroids were, on average, less than $30 \mathrm{~km}$ (range: $1.8-172 \mathrm{~km}$ ) apart. Bears in this region seem to exhibit a stronger site fidelity than those reported from other parts of the species range. These findings also highlight the importance of maternal learning in space use.
\end{abstract}

\section{Introduction}

Philopatry, also known as site fidelity, is common among mammals and refers to an individual's faithfulness to specific regions (Greenwood 1980; Rydell 1989). Philopatry influences the distribution of animals as many of them restrict their movement to particular HRs that provide suitable habitats for survival and reproduction (Burt 1943; Clutton-Brock \& Lukas 2012). In some cases, animals disperse far from their natal site, while in others they exhibit natal philopatry by remaining close to or within the region where they were born. In the case of migratory species, animals are philopatric when returning to specific stop-overs, breeding and feeding grounds (Greenwood 1980; Clutton-Brock \& Lukas 2012; Baker et al. 2013; Horton et al. 2017). Animal movements are driven by the availability and variability of resources, such as food, mates and shelters, in space and time (Lewis \& Murray 1993; Dingle \& Drake 2007; Lawson Handley \& Perrin 2007). Many factors influence philopatry and dispersal patterns, such as inbreeding avoidance, competition for resources, habitat predictability and kin competition (Switzer 1993; Perrin \& Mazalov 1999; Lawson Handley \& Perrin 2007). In solitary mammalian species, philopatry and dispersal patterns have important consequences on kinship structures (Clutton-Brock \& Lukas 2012). Kinship structures exist when the proximity between individuals is strongly associated with their degree of relatedness (Maher 2009; Clutton-Brock \& Lukas 2012). These structures can increase reproductive success, and, thus, the individual fitness (Lambin \& Krebs 1993; Pope 2000). In mammals, philopatry is often sex biased: females tend to be more philopatric than males, which favours female kin 
structures. The direction of the sex bias is thought to be primarily due to the mating system (Greenwood 1980). In polygynous species, females greatly invest in their offspring and are the limiting sex encouraging males to disperse. By dispersing, males increase their probability to mate, which enhances their reproductive success. These attributes exist in ursids, such as in the American black bear (Ursus americanus), the brown bear (U. arctos) and the polar bear (U. maritimus; Rogers 1987; Stoen et al. 2005; Zeyl, Aars, Ehrich \& Wiig O. 2009).

The largest of all ursids, the polar bear is a solitary predator endemic to the Arctic. Polar bears are usually found on sea ice for most of the year and can also spend periods on the land, up to several months in summer and autumn in some areas, waiting for sea ice to reform (Amstrup 2003). In the Barents Sea subpopulation, two distinct stable ecotypes exist (Mauritzen et al. 2001). Offshore bears are predominantly found along the marginal ice zone as they follow the sea-ice advance and retreat. In contrast, coastal bears remain within the Svalbard archipelago year-round using primarily land-fast ice and glacier fronts rather than the drifting pack ice (Freitas et al. 2012). When sea ice is locally absent, these coastal bears travel on land and across open water (Freitas et al. 2012; Hamilton, Kovacs, Ims, Aars \& Lydersen $2017)$. These contrasting spatial patterns result in considerable inter-individual variations in HR sizes within the Barents Sea subpopulation (Mauritzen et al. 2001; Aars et al. 2009; Obbard et al. 2010; Blanchet et al. 2020). Offshore bears typically travel large distances across the Barents Sea region, whereas coastal bears are limited to land and nearshore areas. Site fidelity in Barents Sea polar bears has been previously documented for both ecotypes (Wiig 1995; Mauritzen et al. 2001; Zeyl et al. 2010; Lone et al. 2013). For instance, Mauritzen et al. (2001) used satellite telemetry to track females in the Barents Sea region throughout the year. They found that individuals of both ecotypes were philopatric, with a season-specific fidelity among the offshore bears. Studies based on satellite telemetry data in polar bears are restricted to females because male bears have thick necks, which cannot be collared. However, capture-mark-recapture methods can provide insights on site fidelity for both sexes. Lone et al. (2013) showed that individuals of both sexes in Svalbard are faithful to specific areas in the spring, although females exhibited a higher degree of site fidelity than males. Mark-recapture methods combined with genetic analysis suggested that the offspring remain close to their mothers' areas, including during the denning period (Zeyl, Aars, Ehrich \& Wiig 2009; Zeyl et al. 2010).

Although philopatry is a known feature of polar bears in the Barents Sea region, little is known about intraindividual variability, the influence of kinship on space use and the extent to which such attributes are temporally stable. This study used high-resolution GPS telemetry data over an eight-year period to investigate multi-year philopatry in coastal female polar bears. The objectives of this study were to determine whether the space use of individual coastal female polar bears was (1) stable over time, (2) influenced by seasonality and (3) linked to kinship.

\section{Methods}

\section{Study site}

The High-Arctic Archipelago of Svalbard encompasses $62000 \mathrm{~km}^{2}$, which is located at $74-81{ }^{\circ} \mathrm{N}$ and $10-35^{\circ} \mathrm{E}$ (Fig. 1). Atlantic water flows northwards and enters the Arctic Ocean through Fram Strait to the west of Svalbard and the Barents Sea to the east (Loeng 1991; Piechura \& Walczowski 2009; Przybylak et al. 2014). The amount of heat transported by the WSC has been increasing in the last few decades, negatively impacting the seasonal seaice cover and thickness in the archipelago (Gerland et al. 2008; Piechura \& Walczowski 2009). Warming of the WSC can locally prevent ice formation, especially in coastal areas. A lack of fast ice in western Svalbard was observed in 2005/06 compared with the preceding decade (Cottier et al. 2007). Since 2006, the fjord systems transitioned from an Arctic state to a more Atlantic state along the west coast of Spitsbergen (Cottier et al. 2007; Muckenhuber et al. 2016). In the Svalbard region, the maximum sea-ice extent typically occurs in March or April, while the minimum sea-ice extent occurs in September or October (Loset \& Carstens 1996; Muckenhuber et al. 2016).

\section{Capture and instrumentation}

Satellite telemetry data were collected over an eightyear period (2011-19) as part of an ongoing annual research programme on the ecology of polar bears led by the Norwegian Polar Institute since 1987. Polar bears were captured by chemical immobilization using a projectile syringe distributed from a capture rifle. The rifle was fired from a helicopter (Eurocopter AS350 Ecureuil). We used medetomidine and tiletamine-zolazepam mixture (Zoletil 50, (B Vibrac), with a standard induction dose of $1400 \mathrm{mg}$ for adult females, following the standard protocols of Stirling et al. (1989). Apparently, healthy adult females ( $\geq$ five years) were equipped with Telonics TGW4678-3 or TGW-4678-4 GPS satellite transmitters (Blanchet et al. 2020). In addition to positional data, activity and temperature were recorded. Following the method outlined by Blanchet et al. (2020), we identified maternity denning by a low-activity signature, 


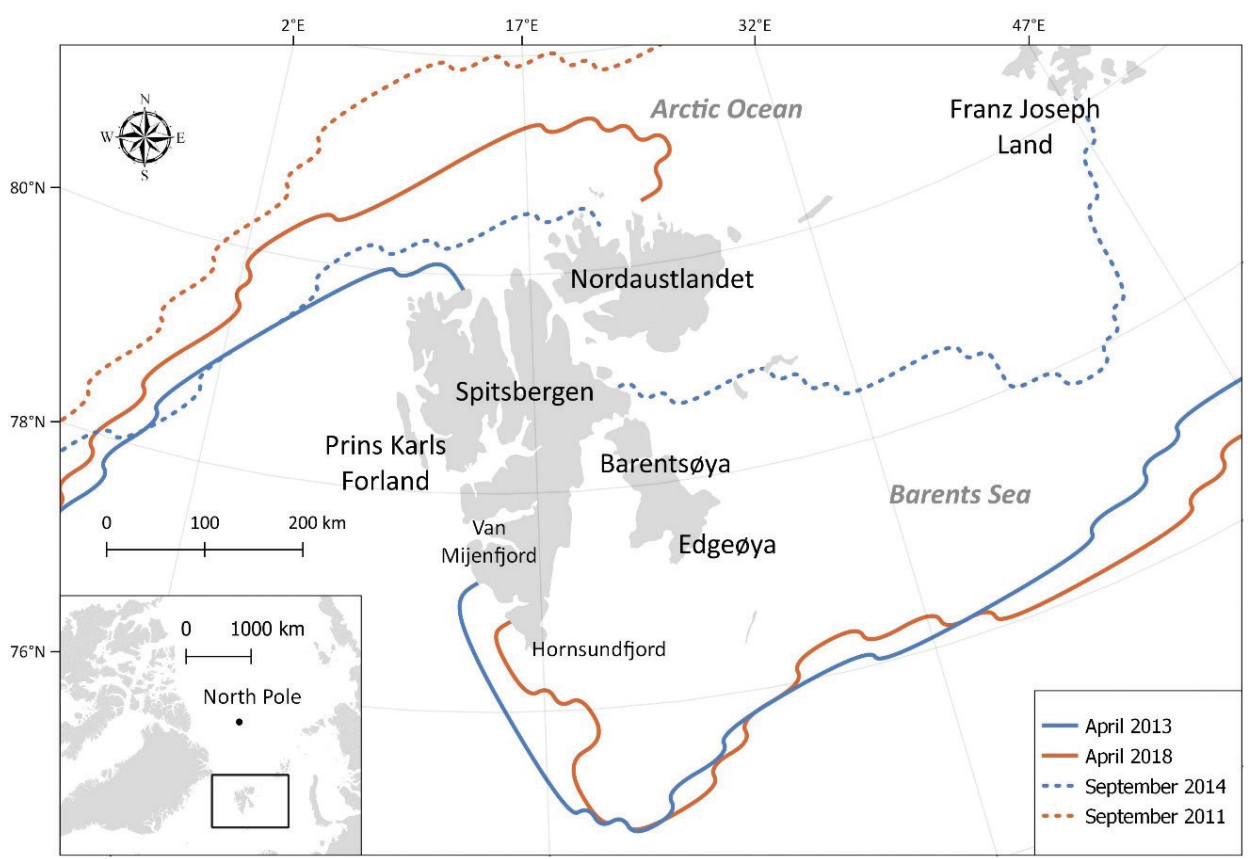

Fig. 1 Map of the Barents Sea region: the High-Arctic archipelago of Svalbard and part of the western Russian Arctic. The inset displays the Barents Sea region from a circumpolar perspective. The lines represent the annual maximum (April) and minimum (September) sea-ice extents (15\% concentration threshold). The colour scheme corresponds to extremes in sea-ice extent observed during the 2011-19 study period. The most extreme years are displayed to show the interannual variability during the study period. Note that the lines correspond to different years, as the observed extremes did not occur within the same year.

consistent temperature $>0{ }^{\circ} \mathrm{C}$ and lack of movement for long periods (minimum of 14 days) during winter. A denning event had to start between 1 October and 31 December. Activity duration was measured using an accelerometer recording the number of seconds an animal was in movement (but not necessarily in displacement) per period of time (six hours in 2011 and 2012; two hours from 2014 onwards). The Norwegian Animal Research Authority approved all animal handling and protocols. The work was carried out in accordance with the relevant guidelines and regulations under permits issued by the Governor of Svalbard.

Seventeen out of the 89 adult female polar bears that were equipped with GPS collars between 2011 and 2019 were selected for this research study. These 17 female polar bears were mostly captured during April $(n=34)$, but some collars were also fitted in March $(n=1)$ and September $(n=$ 2 ). This subset included females that were tracked for at least two years (consecutive or non-consecutive years), as well as related females (mothers-daughters or sisters) tracked for at least one full year each. The relatedness of the females was identified using the extensive database of the Norwegian Polar Institute. Cubs are fitted with a permanent ear tag when captured with their mother and can be instrumented as adults with a satellite transmitter.

\section{Data analysis}

The data set was divided into two subsets: (1) a subset of females used to assess the intra-individual variability in site fidelity ( $n=13$, Table 1$)$ and (2) a subset of related females used to explore the influence of kinship on site fidelity ( $n=11$, females belonging to five different matrilines; Table 2). Seven out of the 17 female bears were used in both analyses, and all individual bears belonged to the coastal ecotype.

All numerical analyses were performed using the software R ( $\mathrm{R}$ studio version 1.1.384; $\mathrm{R}$ Core Team 2017). Location estimates were obtained by GPS via the Argos (Collecte Localisation Satellites) or Iridium systems (Iridium Satellite Communications). Instruments were programmed to transmit every two hours, with no duty cycle. Satellite signals can be affected by physical constraints and be altered when individuals are denning or in water, resulting in gaps in the data stream. This occurred rarely as time steps between two consecutive GPS locations were less than four hours for $90 \%$ of the time (total number of locations recorded: 95 271). Locations were processed with a Kalman filter under a state-space model framework using the $\mathrm{R}$ package "crawl" (Johnson et al. 2008) to produce a model of the most probable path taken by an animal. Using this model, locations were predicted every two hours. A full year 
started from 1 June and ended 31 May the following year. Seasons were defined as follows: spring (June-July), summer (August-September), autumn (October-November) and winter (December-May).

Annual and seasonal HRs were obtained using the MCP method (Mohr 1947). This non-parametric method uses the smallest convex polygon capturing the locations of an animal. As convex polygons are formed using extreme locations in space, the area encompassed by a polygon is very sensitive to outliers or excursions deviating from a core area. In order to minimize this bias, the analysis was run with polygons enclosing $50 \%$ of the locations focusing on the core region occupied by individuals. The 50\% MCPs were delineated using the function "mcp" in the R package "adehabitatHR" (Calenge 2006). GPS locations collected during the denning periods were removed to compare only active space use and avoid introducing bias by comparing denning and non-denning individuals. Seventeen denning periods

Table 1 Summary of the biological data of Svalbard coastal female polar bears for the intra-individual analysis.

\begin{tabular}{llcc}
\hline IDs & Recorded years & $\begin{array}{c}\text { Number of } \\
\text { collars }\end{array}$ & $\begin{array}{c}\text { Total } \\
\text { duration (days) }\end{array}$ \\
\hline A & $11-12,15-16$ & 3 & 676 \\
B & $14-15,17-18$ & 2 & 645 \\
Ba & $14-15,15-16,18-19$ & 3 & 1095 \\
C & $11-12,15-16$ & 2 & 690 \\
Da & $15-16,17-18$ & 3 & 701 \\
Ea & $17-18,18-19$ & 3 & 728 \\
Eb & $11-12,15-16$ & 2 & 605 \\
F & $14-15,15-16,17-18$ & 4 & 1095 \\
G & $13-14,17-18$ & 3 & 688 \\
H & $14-15,15-16,17-18,18-19$ & 2 & 1409 \\
I & $17-18,18-19$ & 1 & 730 \\
J & $15-16,16-17,17-18$ & 1 & 1095 \\
K & $14-15,15-16$ & 1 & 694 \\
\hline
\end{tabular}

were identified for 12 individuals and were subsequently removed. In order to determine intra-individual variations in annual HR size, relative differences in percentages were calculated between an individual's largest and smallest HRs. The same metrics were used for kinship analysis: differences were calculated between individuals belonging to the same matriline. When an individual was tracked for more than one full year within a matriline, a mean HR size was calculated to compute HR centroid distances and overlap between related animals.

A centroid or geometric centre of a plane figure refers to the arithmetic mean of all the points in the HR polygon. The locations of annual and seasonal HR centroids were calculated using the function "gCentroid" from the "rgeos" package (Bivand \& Rundel 2018). These centroid positions were used to calculate distances between HRs. The matrix of distances between all centroids was computed using the "pointDistance" function from the "geosphere" package (Hilmans 2019). Inter-individual and intra-individual distances between annual and seasonal HRs were calculated. In order to determine whether the distances between centroids differed between seasons, a Kruskal-Wallis test was carried out. The distribution of the data did not meet the assumptions for a parametric test of analysis of variance (Shapiro test: $p<0.05$ ). A posthoc pairwise Wilcoxon signed-rank test was used to assess which seasons significantly differed from others. Percentages of HR overlaps were calculated for each HR pair using the following equation:

$$
\frac{(\text { area of overlap between HRs A \& B })}{(\text { area A + area B - area of overlap between A \& B })} \times 100
$$

A Spearman's rank coefficient was calculated to determine whether differences in HR overlap were correlated with the time gap (i.e., number of years) between two HRs.

Table 2 Summary of the biological data of Svalbard coastal female polar bears for the kinship analysis. Eleven female polar bears form five matrilines named from A to E. Unique capital letters refer to mothers, double letters to daughters or sisters, with the first letter referring to the mother's identifica-

\begin{tabular}{|c|c|c|c|c|}
\hline IDs & Year of birth & Recorded years & Number of collars & Total duration (days) \\
\hline$A$ & 1995 & $11-12,15-16$ & 3 & 676 \\
\hline $\mathrm{Aa}$ & 2002 & $15-16$ & 2 & 365 \\
\hline B & 1993 & $14-15,17-18$ & 2 & 730 \\
\hline $\mathrm{Ba}$ & 2008 & $14-15,15-16,18-19$ & 3 & 1074 \\
\hline $\mathrm{Bb}$ & 2012 & $18-19$ & 1 & 312 \\
\hline C & 1991 & $11-12,15-16$ & 2 & 690 \\
\hline $\mathrm{Ca}$ & 2011 & $18-19$ & 1 & 365 \\
\hline $\mathrm{D}$ & 1996 & $15-16$ & 1 & 365 \\
\hline $\mathrm{Da}$ & 2006 & $15-16,17-18$ & 3 & 670 \\
\hline Ea & 2006 & $17-18,18-19$ & 3 & 728 \\
\hline $\mathrm{Eb}$ & 2003 & $11-12,15-16$ & 2 & 664 \\
\hline
\end{tabular}
tion. Year of birth assumes birth occurred after 1 January. 


\section{Results}

\section{Intra-individual variability}

The number of years of data per individual ranged from two to four years, with a total of 31 bear years overall. For distances and overlap analyses, nine comparisons were made between consecutive years, while 15 comparisons were made between non-consecutive years. On average, the difference between non-consecutive years was two years, with a maximum difference of four years. Annual HR sizes ( $50 \%$ polygons) of the Svalbard coastal female polar bears varied from 96 to $22545 \mathrm{~km}^{2}$ (Fig. 2, Table 3). Female $\mathrm{C}$ had the two largest annual HRs, 21371 and 22 $545 \mathrm{~km}^{2}$, in 2011/12 and 2015/16, respectively (Fig. 2). Female Eb recorded the two smallest annual HRs of 105 $\mathrm{km}^{2}$ and $96 \mathrm{~km}^{2}$ in 2011/12 and 2015/16, respectively (Fig. 2a). Intra-individual annual HR sizes varied between years (Figs. 2a, 3). The difference between the largest HRs and the smallest HRs corresponded, on average, to $42.8 \%$ and varied between 5.2 and $91.8 \%$ (Fig. 3). Female F showed the largest variation in HR size of $91.8 \%$ (Fig. 3 ). Centroids of HRs belonging to the same individual were closer than those of HRs belonging to different animals. An average of $15 \mathrm{~km}$ (SD $=17 \mathrm{~km}$, range: $2-63 \mathrm{~km}$ ) separated locations between HR centroids belonging to the same individuals, while an average of $173 \mathrm{~km}$ (SD = $89 \mathrm{~km}$, range: 7-392 km) separated locations between separate individual's HR centroids (Fig. 2a, Table 3). The minimum distance between the annual HR centroids of the same bear was $2 \mathrm{~km}$ between 2015/16 and 2018/19 (Fig. 2, Table 3), while the maximum distance recorded was $63 \mathrm{~km}$ between 2014/15 and 2017/18 (Fig. 2, Table 3). Annual HRs belonging to the same bear overlapped with an average of 44\% (range: 9-96\%; Fig. 2, Table 3). There was no correlation between the length of time gaps between annual HRs and percentages of overlap (Spearman's rank correlation coefficient, $\mathrm{S}=2083.1$, $p=0.66)$.

Individual HR sizes varied between seasons (KruskalWallis chi-squared $=35.161, d f=3, p=0.00)$. The largest HR sizes were reported in spring $\left(2915 \mathrm{~km}^{2}, \mathrm{SD}=4809\right)$ followed by winter $\left(1284 \mathrm{~km}^{2}, \mathrm{SD}=1488\right)$, summer $(792$ $\left.\mathrm{km}^{2}, \mathrm{SD}=1728\right)$ and then autumn $\left(268 \mathrm{~km}^{2}, \mathrm{SD}=279\right.$; Table 3). Distances between season-specific individual HR centroid positions were, on average, below $30 \mathrm{~km}$ (range: 1.8-172 km; Fig. 4a). Distances were the highest for the spring season (mean $30 \mathrm{~km}, \mathrm{SD}=45 \mathrm{~km}$, range: $2-172$ $\mathrm{km}$ ) and the lowest for autumn (mean $14 \mathrm{~km}, \mathrm{SD}=11$ km, range: 2-50 km; Fig. 4a, Table 3). These differences
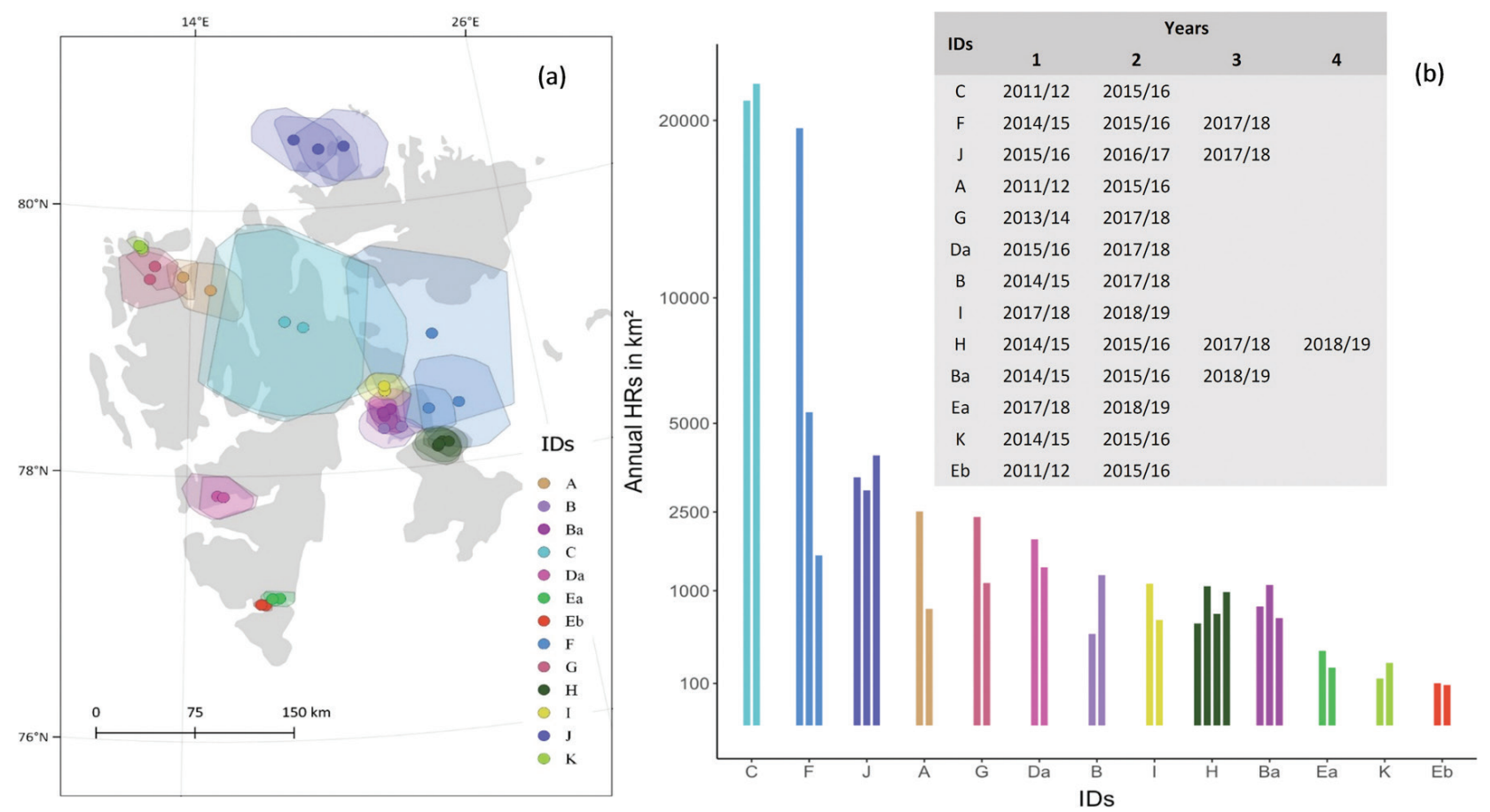

Fig. 2 (a) Annual HRs defined as 50\% MCPs for 13 coastal female polar bears instrumented in Svalbard between 2011 and 2019. Each polygon is colourcoded per individual. The points represent the centroids for each polygon. (b) Areas of annual HRs for the same female polar bears in $\mathrm{km}^{2}$. The number of bars, which are colour-coded as in (a), depends on the number of full years an individual was tracked. Individual's bars are organized chronologically (see the explanatory table). Note that the scale of the $y$ axis was square root transformed. 
Table 3 Summary of the analysis of annual and seasonal HR of Svalbard coastal female polar bears instrumented from 2011 to 2019 . Intra-individual analysis: distances between HR centroids and percentages of HR overlaps were calculated using the same individuals. Kinship analysis: distances between HR centroids and percentages of HR overlaps were calculated using related bears belonging to the same matriline.

\begin{tabular}{|c|c|c|c|c|c|c|c|}
\hline & & \multicolumn{3}{|c|}{$\begin{array}{c}\text { Intra-individual } \\
(n=29 ; n=13 ; n=31)^{\mathrm{a}}\end{array}$} & \multicolumn{3}{|c|}{$\begin{array}{c}\text { Kinship } \\
(n=23 ; n=11 ; n=19)^{\mathrm{a}}\end{array}$} \\
\hline & & Mean & Median & Range & Mean & Median & Range \\
\hline & Annual tracking duration (days) & 353.3 & 365 & $299-365$ & 348.9 & 365 & $299-365$ \\
\hline \multirow[t]{2}{*}{ Year } & HR size $\left(\mathrm{km}^{2}\right)$ & 3273 & 1097 & $96-22545$ & 3456 & 1097 & $96-22545$ \\
\hline & HR overlap (\%) & 44.2 & 44.4 & $8.5-95.8$ & 23.8 & 24.9 & $0-66$ \\
\hline \multirow[t]{3}{*}{ Spring } & HR size $\left(\mathrm{km}^{2}\right)$ & 2915 & 1349 & $36-22648$ & 3215 & 1741 & $36-22648$ \\
\hline & Distances HR centroids (km) & 29.7 & 17.7 & $1.9-172$ & 38 & 29 & 9.9-109.3 \\
\hline & HR overlap (\%) & 25.2 & 23.8 & $0-79$ & 9.2 & 4.5 & $0-35$ \\
\hline \multirow[t]{2}{*}{ Summer } & HR size $\left(\mathrm{km}^{2}\right)$ & 792 & 325 & $12-9522$ & 905 & 279 & $27-9522$ \\
\hline & HR overlap (\%) & 20.5 & 22.6 & $0-50$ & 15 & 7.8 & $0-69.7$ \\
\hline \multirow[t]{3}{*}{ Autumn } & HR size $\left(\mathrm{km}^{2}\right)$ & 268 & 204 & $3-1311$ & 270 & 203 & $22-945$ \\
\hline & Distances HR centroids (km) & 14 & 12 & $1.8-50.5$ & 19.6 & 17.7 & $2.6-54.8$ \\
\hline & HR overlap (\%) & 12.5 & 5.4 & $0-67.5$ & 7.2 & 0 & $0-51.4$ \\
\hline \multirow[t]{3}{*}{ Winter } & HR size $\left(\mathrm{km}^{2}\right)$ & 1284 & 833 & $0.8-6390$ & 1241 & 833 & $0.8-6390$ \\
\hline & Distances HR centroids (km) & 16.3 & 12.5 & $2.4-44.4$ & 19.8 & 21 & $1.5-34$ \\
\hline & HR overlap (\%) & 25.3 & 23 & $0-63.3$ & 12.7 & 7.8 & $0-76$ \\
\hline
\end{tabular}

${ }^{a}$ Number of collars; number of bears; number of years.

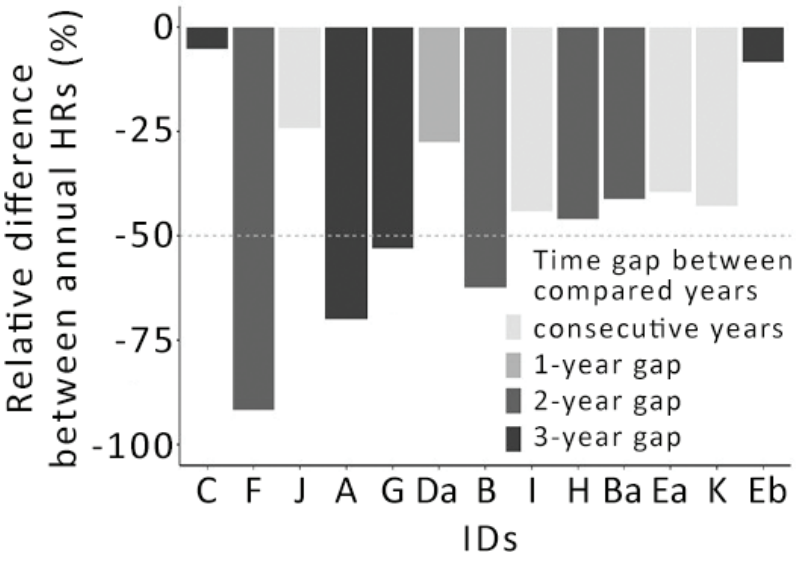

Fig. 3 Relative intra-individual variation between the largest and the smallest annual HR areas for 13 female polar bears instrumented in Svalbard between 2011 and 2019

between seasons were, however, not statistically significant (Kruskal-Wallis test; chi-squared $=1.6702, d f=3$, $p=0.64$; Fig. 6a). The minimum distance between seasonal HR centroids of the same bear was $2 \mathrm{~km}$ in the autumn (Table 3), and the maximum distance was $172 \mathrm{~km}$ in the spring (Table 3 ).

\section{Kinship}

The number of years of data per individual ranged from one to three years, with a total of 19 bear years overall. For distances and overlap analyses, three comparisons were made between records of the same year, three were between consecutive years and 15 were between non-consecutive years. There were three motherdaughter pairs, one mother with two daughters from different litters, and two sisters from different litters. HR sizes varied across matrilines and ranged from 96 to

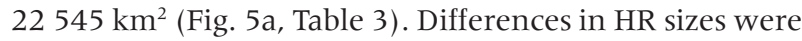
small between individuals belonging to the same matriline (mean $3815 \mathrm{~km}^{2}$, range: 15-20 $499 \mathrm{~km}^{2}$ ). Within the matriline $\mathrm{B}$, the mother and her two daughters, Ba and Bb, had very similar HR sizes: 864,844 and $829 \mathrm{~km}^{2}$. The two sisters in matrilines $\mathrm{E}$ had the smallest HR sizes among all the matriline members: $254 \mathrm{~km}^{2}$ and $100 \mathrm{~km}^{2}$. Bears of matriline $\mathrm{C}$ showed the largest differences, with an annual HR size of $21958 \mathrm{~km}^{2}$ for the mother and 1459 $\mathrm{km}^{2}$ for the daughter. Related bears utilized similar regions of the archipelago (Fig. 5a). Annual HR centroid positions of related individuals were much closer than those of non-related individuals. An average of $18 \mathrm{~km}$ $(\mathrm{SD}=13$, range: $2-52 \mathrm{~km})$ separated locations of $\mathrm{HR}$ 

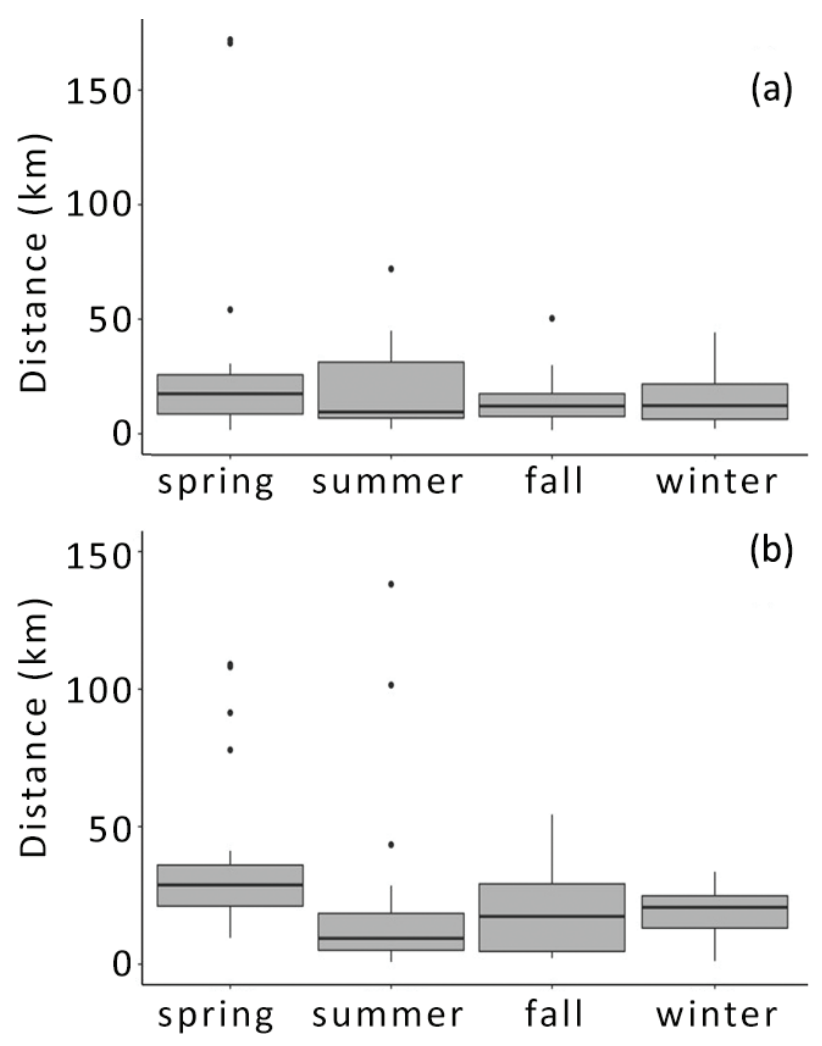

Fig. 4 (a) Distances between seasonal HR centroid positions belonging to the same coastal female polar bear $(n=13)$. (b) Distances between seasonal HR centroid positions between related coastal female polar bears $(n=11)$. All female polar bears were instrumented in Svalbard between 2011 and 2019.

centroid positions of individuals belonging to the same matriline, while an average of $160 \mathrm{~km}$ (SD $=55$, range: 59-283 km) separated locations of HR centroid positions of individuals belonging to different matrilines (Fig. 5a, Table 3). For example, the two sisters of matriline E both utilized the southernmost part of the island of Spitsbergen, spending most of their time in Hornsund fjord (Fig. 5a). Twenty out of the 21 pairs of annual HRs belonging to bears of the same matriline overlapped (Fig. 5a). On average, pairs of annual HRs of related bears overlapped by 24\% (range: $0-66 \%$ ). The only pair of HRs not overlapping was between the female Ea in 2015/16 and her sister Eb in 2017/18. They were still in very close proximity as the centroids of their annual HRs were separated by just $15 \mathrm{~km}$ (Fig. 5a).

Related bears were in close proximity in all seasons (Fig. 4b, Table 3). On average, distances between HR centroid positions of related individuals were below $40 \mathrm{~km}$ for all seasons. Distances were greater in the spring (mean $38 \mathrm{~km}, \mathrm{SD}=31$ ) and smaller in the autumn seasons
(20 km, SD = 14; Fig. 4b, Table 3; Kruskal-Wallis test; chisquared $=12.45, d f=3, p=0.01)$. Wilcoxon signed-rank tests revealed that only spring distances were significantly greater than other seasons (Fig. 4b; significant pairwise tests: spring-summer $p<0.01$, spring-autumn $p=0.01$, spring-winter $p=0.02$ ). The minimum distance between seasonal HRs of related bears was $1 \mathrm{~km}$ for sisters Ea and $\mathrm{Eb}$ in winter, while the maximum distance was $138 \mathrm{~km}$ between mother $\mathrm{C}$ and her daughter in summer.

\section{Discussion}

The results of this study are consistent with those of previous research study on coastal polar bear site fidelity in the Barents Sea region (Wiig 1995; Mauritzen et al. 2001; Lone et al. 2013), where individuals seem to be more philopatric than reported in other parts of the species range. For example, in north-east Greenland and eastern Canada, mark-recapture displacements were higher, and HR sizes were larger (Born et al. 1997; Taylor et al. 2001). In this study, coastal females showed a very high degree of temporally stable philopatry. Individuals used the same areas year after year, suggesting that long-term site fidelity is a spatial strategy for this ecotype (Zeyl, Aars, Ehrich \& Wiig 2009; Lone et al. 2013). We also found that kinship influenced the space use of related individuals, with mothers and daughters remaining in close proximity.

Despite living in a highly dynamic environment and having a great dispersal potential, the coastal female polar bears we studied maintained a remarkably stable space use over time. Long-term site fidelity may enhance animals' knowledge of the geography, travel routes and foraging sites within their HRs. At the same time, site-faithful animals avoid the costs associated with dispersal, such as the need to familiarize themselves with new sites and displacement costs (Switzer 1993). Switzer (1993) argued that in unpredictable environments philopatry is related to the quality of HRs: animals should remain within a particular territory when surrounding territories are of equal or lower quality. The fact that coastal females remain faithful to their site may indicate occupancy of the most optimal areas on local scales or, alternatively, that Svalbard offers little heterogeneity in the habitat quality. Furthermore, site-faithful coastal females have a lower overall energetic expenditure compared with the offshore ecotype, which travels longer distances (Blanchet et al. 2020; Pagano et al. 2020). The polygynous mating system of polar bears means that only females are likely to display such a pronounced degree of philopatry. Females do not have to disperse to access unrelated males for reproduction as males roam over larger areas during 

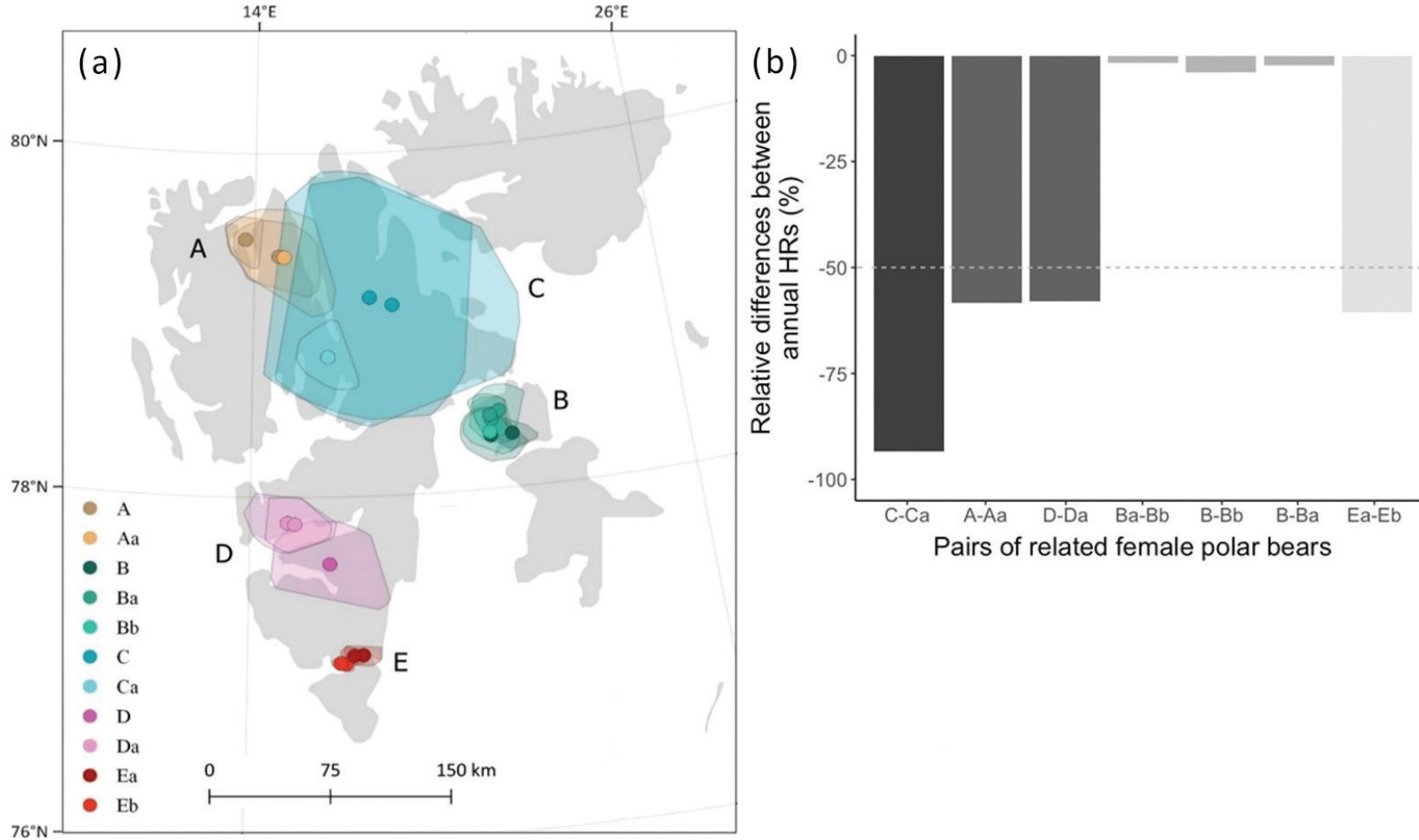

Fig. 5 (a) Annual HR defined as 50\% MCPs for 11 related coastal female polar bears belonging to five different matrilines instrumented in Svalbard between 2011 and 2019. Related animals were coded with similar colours and letters (mothers are named using a unique capital letter and daughters and sisters are named using two letters, with the first letter referring to the mother's identification). The points represent the centroids for each polygon. (b) Relative variation between the largest and the smallest annual HR areas between pairs of related females.

the breeding season in the effort to maximize encounters with receptive females (Greenwood 1980; Clutton-Brock \& Lukas 2012; Laidre et al. 2013). In addition, the strong philopatry exhibited by female individuals might favour male dispersal. However, data from Svalbard show that males are also surprisingly faithful to certain areas over years and generations (Zeyl, Aars, Ehrich, Bachmann \& Wiig 2009; Lone et al. 2013). Despite the relatively modest sex bias in dispersal, close inbreeding is very rare in Svalbard (Zeyl, Aars, Ehrich, Bachmann et al. 2009). Coastal bears, in contrast to their offshore counterparts, remain close to the Svalbard archipelago year-round (Mauritzen et al. 2001; Aars et al. 2017). They use landfast ice as a platform to travel and spend a significant time foraging at glacier fronts in spring and early summer (Freitas et al. 2012; Hamilton, Kovacs, Ims, Aars \& Lydersen 2017). However, some bears also use the marginal ice zone in the spring and summer, moving away from coastal areas. Foraging strategies may be individual specific. These individual strategies seem to be stable over time and differ considerably between females. Individuals targeting fjords and glacier fronts as main foraging habitats likely encounter a higher abundance of prey than the ones utilizing mostly the pack ice habitat where seals are sparsely distributed. This could explain large interindividual variations in HR size. Some of the coastal females used less than $1000 \mathrm{~km}^{2}$ annually. These HR sizes seem to be very small compared with averages found in other parts of the species range (Born et al. 1997; Ferguson et al. 1999; Amstrup et al. 2000). For example, Ferguson et al. (1999) have found an average home range size of $125000 \mathrm{~km}^{2}$ ( \pm 11 800) for female polar bears in the Canadian Arctic. This could be partly explained by the so-far predictable ice conditions in fjord systems and by the large amount of coastline habitat enhancing local productivity (Ferguson et al. 1999).

Intra-individual differences in annual HR size were observed for all individuals. They were generally small but some individuals showed a variation of nearly 100\% (i.e., no overlap) between their largest and smallest HRs. These differences are possibly linked to external factors, such as changes in environmental conditions like local sea-ice distribution (Garner et al. 1990). Internal factors, such as reproductive status, are also known to affect movement patterns of female bears. Amstrup et al. (2000) documented that female polar bears with young 
cubs moved less compared with those with older cubs or solitary females. The presence of cubs is linked to a decrease in range size in female brown bears as a defence mechanism against males' infanticide behaviour (Dahle \& Swenson 2003). Female polar bears are likely to exhibit similar behavioural patterns because adult males are known to prey on dependent cubs (Derocher \& Wiig 1999; Amstrup 2003; Stone \& Derocher 2007). Coastal female polar bears exhibited a strong site fidelity in all seasons. In the spring, increased mobility is associated with a peak of prey availability as seals pup on ice (Messier et al. 1992; Lydersen 1998). This increase in foraging activity is linked to larger HR sizes in comparison with the other seasons and is consistent with other studies from the same region (Blanchet et al. 2020). Distances between individual's spring HR centroids were less than $30 \mathrm{~km}$, on average, indicating faithfulness to foraging areas. The degree of site fidelity was even higher during the summer, autumn and winter, resulting in smaller HRs and shorter distances between intra-individual HR centroids compared with the spring. The smaller HR sizes in the summer, autumn and winter, reflect a lower activity level, presumably due to limited food availability combined with more severe seasonal environmental conditions (Messier et al. 1992).

A strong relationship between spatial proximity and genetic relatedness was found in Svalbard coastal female polar bears. Relatives were found in close proximity yearround, which is consistent with the findings of Zeyl, Aars, Ehrich, Bachmann \& Wiig (2009), who documented a social structure based on female kin in the Barents Sea subpopulation during the mating season in spring. All annual HRs belonging to related bears overlapped with one exception. In the latter, the annual HR centroids of the two sisters were only $15 \mathrm{~km}$ apart. Annual HR centroids of mother-daughter and sister pairs were, on average, less than $20 \mathrm{~km}$ apart. This negative correlation between distance and relatedness was weaker in the spring compared with the other seasons, probably because HR sizes are bigger in the spring, when foraging activity peaks. Other ursids have female kinship structures, such as the brown bear, whose relatedness determines proximity and HR overlap among females (Stoen et al. 2005; Moyer et al. 2006; Zedrosser et al. 2007). Despite living in very different environments, Scandinavian brown bears and Svalbard polar bears seem to exhibit a similar female kinship structure (Yu et al. 2004; Stoen et al. 2005). Natal philopatry might be favoured when familiarity to foraging areas and the acquisition of specific foraging techniques are crucial for survival (Waser et al. 1983; Lawson Handley \& Perrin 2007). In the black bear, Hopkins (2013) showed that mother-offspring social learning is a mechanism partly responsible for the choice of foraging sites at adulthood. This might also be the case in polar bears, whose cubs stay with their mothers for several years learning where and how to hunt, the main hunting techniques being stalking and still-hunting (Stirling 1974). Additionally, tolerance and cooperation through kin can favour natal philopatry (Waser et al. 1983; Silk 2007; Clutton-Brock \& Lukas 2012; Odden et al. 2014; Smith 2014). For the brown bear, Zedrosser et al. (2007) hypothesized that the increase in tolerance among related females decreases the probability of natal dispersal. The percentage of HR overlap and the proximity among related female polar bears suggest that individuals manifest a certain degree of tolerance towards each other. Although polar bears lack territoriality, individuals may fight over killed prey or carcasses (Stirling 1974). Kin recognition may reduce or eliminate aggressive behaviours among closely related bears. The mechanisms behind kin recognition are unknown for the polar bears but are documented in some other species of mammals. Mateo (2002) showed that Belding's ground squirrels (Spermophilus beldingi) produce odours linked to relatedness. In spotted hyenas (Crocuta crocuta), visual, acoustic and olfactory signals can be used to distinguish kin from non-kin (Holekamp et al. 2007). Lode (2008) suggested that kin recognition in the European polecat (Mustela putorius), a solitary mustelid species, might be based on familiarization rather than on specialized kin recognition systems. In this case, familiarization influences behaviour and may reduce antagonistic encounters (Tang-Martinez 2001; Lode 2008). In coastal female polar bears, motherdaughter and sister-sister pairs may maintain familiarity by staying in close proximity with and encountering each other regularly. Whether the close proximity between related coastal female polar bears increases the individual fitness through cooperation or tolerance remains unknown.

\section{Conclusion}

The findings of this study are restricted to female polar bears of the coastal ecotype. Individuals of the offshore ecotype also exhibit site fidelity, although, to a lesser degree, (Mauritzen et al. 2001) and likely influenced by sea-ice phenology as their habitat has shifted up to several $100 \mathrm{kms}$ north in recent years (Lone et al. 2018). In Svalbard, profound changes in sea-ice and glacier-front conditions are affecting Arctic marine mammals (Kovacs et al. 2011). By remaining highly philopatric, coastal female polar bears are particularly vulnerable to climate change as they ultimately depend on local environmental conditions. Coastal fast-ice areas and glacier fronts are greatly reduced, decreasing the essential polar bear 
foraging habitat (Freitas et al. 2012; Hamilton, Kovacs, Ims, Aars \& Lydersen 2017). Consequently, bears turn to alternative food sources, such as ground-nesting birds, and spend more time on the land during the summer and autumn, which affects their survival and recruitment (Rode et al. 2014; Prop et al. 2015; Atwood et al. 2016; Hamilton, Kovacs, Ims, Aars \& Lydersen 2017; Hamilton, Kovacs, Ims, Aars, Strøm et al. 2017). With increasing loss of sea ice, the bears may be forced to modify their space-use strategy by becoming less philopatric. Future alteration of the sea-ice habitat around Svalbard will continue to have profound impacts on polar bears of the coastal ecotype, particularly on the individuals that restrict their space use to very small regions of the archipelago.

\section{Acknowledgements}

Magnus Andersen participated in the fieldwork throughout the study period. The Airlift helicopter company participated in all field operations.

\section{Disclosure statement}

The authors report no conflict of interest.

\section{Funding}

World Wildlife Fund contributed significantly with funding both collars and helicopter time.

\section{References}

Aars J., Marques T.A., Buckland S.T., Andersen M., Belivok S., Boltunov A. \& Wiig O. 2009. Estimating the Barents Sea polar bear subpopulation size. Marine Mammal Science 25, 35-52, doi: 10.1111/j.1748-7692.2008.00228.x.

Aars J., Marques T.A., Lone K., Andersen M., Wiig O., Floystad I.M.B., Hagen S.B. \& Buckland S.T. 2017. The number and distribution of polar bears in the western Barents Sea. Polar Research 36, article no. 1374125, doi: 10.1080/17518369.2017.1374125.

Amstrup S. 2003. The polar bear, Ursus maritimus. In G.A. Feldhamer et al. (eds.): Wild mammals of North America: biology, management, and conservation. 2nd edn. Pp. 587610. Baltimore, MD: Johns Hopkins University Press.

Amstrup S., Durner G.M., Stirling I., Lunn N.J. \& Messier F. 2000. Movements and distribution of polar bears in the Beaufort Sea. Canadian Journal of Zoology 78, 948-966, doi: 10.1139/z00-016.

Atwood T.C., Peacock E., McKinney M.A., Lillie K., Wilson R., Douglas D.C., Miller S. \& Terletzky P. 2016. Rapid environmental change drives increased land use by an Arctic marine predator. PLoS One 11, e0155932, doi: 10.1371/ journal.pone.0155932.

Baker C., Steel D., Calambokidis J., Falcone E., GonzalezPeral U., Barlow J., Burdin A.M., Clapham P.J., Ford J.K.B., Gabriele C.M., Mattila D., Rojas-Bracho L., Straley J.M., Taylor B.L., Urban J., Wade P.R., Weller D., Witteveen B.H. \& Yamaguchi M. 2013. Strong maternal fidelity and natal philopatry shape genetic structure in North Pacific humpback whales. Marine Ecology Progress Series 494, 291-306, doi: 10.3354/meps 10508 .

Bivand R. \& Rundel C. 2018. rgeos: Interface to Geometry Engine - Open Source (GEOS). R package version 0.4-2. Accessed on the Internet at https://CRAN.R-project.org/ package $=$ rgeos on 10 December 2018 .

Blanchet M., Aars J., Andersen M. \& Routti H. 2020. Spaceuse strategy affects energy requirements in Barents Sea polar bears. Marine Ecology Progress Series 639, 1-19, doi: 10.3354/meps13290.

Born E.W., Wiig O. \& Thomassen J. 1997. Seasonal and annual movements of radio-collared polar bears (Ursus maritimus) in northeast Greenland. Journal of Marine Systems 10, 67-77, doi: 10.1016/S0924-7963(96)00072-3.

Burt W.H. 1943. Territoriality and home range concepts as applied to mammals. Journal of Mammalogy 24, 346-352, doi: $10.2307 / 1374834$.

Calenge C. 2006. The package adehabitat for the $\mathrm{R}$ software: a tool for the analysis of space and habitat use by animals. Ecological Modelling 197, 516-519, doi: 10.1016/j. ecolmodel.2006.03.017.

Clutton-Brock T. \& Lukas D. 2012. The evolution of social philopatry and dispersal in female mammals. Molecular Ecology 21, 472-492, doi: 10.1111/j.1365-294X.2011.05232.x.

Cottier F.R., Nilsen F., Inall M.E., Gerland S., Tverberg V. \& Svendsen H. 2007. Wintertime warming of an Arctic shelf in response to large-scale atmospheric circulation. Geophysical Research Letters 34, L10607, doi: 10.1029/2007GL029948.

Dahle B. \& Swenson J.E. 2003. Seasonal range size in relation to reproductive strategies in brown bears Ursus arctos. Journal of Animal Ecology 72, 660-667, doi: 10.1046/j.1365-2656.2003.00737.x.

Derocher A.E. \& Wiig O. 1999. Infanticide and cannibalism of juvenile polar bears (Ursus maritimus) in Svalbard. Arctic 52, 307-310, doi: 10.14430/arctic936.

Dingle H. \& Drake V.A. 2007. What is migration? Bioscience 57, 113-121, doi: 10.1641/b5702206.

Ferguson S.H., Taylor M.K., Born E.W., Rosing-Asvid A. \& Messier F. 1999. Determinants of home range size for polar bears (Ursus maritimus). Ecology Letters 2, 311-318, doi: 10.1046/j.1461-0248.1999.00090.x.

Freitas C., Kovacs K.M., Andersen M., Aars J., Sandven S., Skern-Mauritzen M.S., Pavlova O. \& Lydersen C. 2012. Importance of fast ice and glacier fronts for female polar bears and their cubs during spring in Svalbard, Norway. Marine Ecology Progress Series 447, 289-304, doi: 10.3354/ meps09516.

Garner G.W., Knick S.T. \& Douglas D.C. 1990. Seasonal movements of adult female polar bears in the Bering and Chukchi seas. In L.M. Darling \& W.R. Archibald (eds.): Bears: their biology and management. Vol. 8. A selection of papers 
from the Eighth International Conference on Bear Research and Management, Victoria, British Columbia, Canada, February 1989. Pp. 219-226. Victoria: International Association for Bear Research and Management.

Gerland S., Renner A.H.H., Godtliebsen F., Divine D. \& Loyning T.B. 2008. Decrease of sea ice thickness at Hopen, Barents Sea, during 1966-2007. Geophysical Research Letters 35, L06501, doi: 10.1029/2007GL032716.

Greenwood P.J. 1980. Mating systems, philopatry and dispersal in birds and mammals. Animal Behaviour 28, 1140-1 162, doi: 10.1016/S0003-3472(80)80103-5.

Hamilton C.D., Kovacs K.M., Ims R.A., Aars J. \& Lydersen C. 2017. An Arctic predator-prey system in flux: climate change impacts on coastal space use by polar bears and ringed seals. Journal of Animal Ecology 86, 1054-1064, doi: $10.1111 / 1365-2656.12685$.

Hamilton C.D., Kovacs K.M., Ims R.A., Aars J., Strøm H. \& Lydersen C. 2017. Spatial overlap among an arctic predator, prey and scavenger in the marginal ice zone. Marine Ecology Progress Series 573, 45-59, doi: 10.3354/meps 12184.

Hilmans R.J. 2019. geosphere: Spherical Trigonometry. R package version 1.5-10. Accessed on the internet at https:// CRAN.R-project.org/package=geosphere on 3 June 2019.

Holekamp K.E., Sakai S.T. \& Lundrigan B.L. 2007. The spotted hyena (Crocuta crocuta) as a model system for study of the evolution of intelligence. Journal of Mammalogy 88, 545-554, doi: 10.1644/06-MAMM-S-361R1.1.

Hopkins J.B. 2013. Use of genetics to investigate socially learned foraging behavior in free-ranging black bears. Journal of Mammalogy 94, 1214-1222, doi: 10.1644/13-mamm-a-009.1.

Horton T.W., Hauser N., Zerbini A.N., Francis M.P., Domeier M.L., Andriolo A., Costa D.P., Robinson P.W., Duffy C.A.J., Nasby-Lucas N., Holdaway R.N. \& Clapham P.J. 2017. Route fidelity during marine megafauna migration. Frontiers in Marine Science 4, article no. 422, doi: 10.3389/ fmars.2017.00422.

Johnson D.S., London J.M., Lea M.A. \& Durban J.W. 2008. Continuous-time correlated random walk model for animal telemetry data. Ecology 89, 1208-1215, doi: 10.1890/07-1032.1.

Kovacs K.M., Lydersen C., Overland J.E. \& Moore S.E. 2011. Impacts of changing sea-ice conditions on Arctic marine mammals. Marine Biodiversity 41, 181-194, doi: 10.1007/ s12526-010-0061-0.

Laidre K.L., Born E.W., Gurarie E., Wiig O., Dietz R. \& Stern H. 2013. Females roam while males patrol: divergence in breeding season movements of pack-ice polar bears (Ursus maritimus). Proceedings of the Royal Society B 280, article no. 20122371, doi: 10.1098/rspb.2012.2371.

Lambin X. \& Krebs C.J. 1993. Influence of female relatedness on the demography of Townsend's vole populations in spring. Journal of Animal Ecology 62, 536-550, doi: $10.2307 / 5203$.

Lawson Handley L.J. \& Perrin N. 2007. Advances in our understanding of mammalian sex-biased dispersal. MolecularEcology 16, 1559-1578, doi: 10.1111/j.1365-294X.2006.03152.x.

Lewis M.A. \& Murray J.D. 1993. Modelling territoriality of wolf-deer interactions. Nature 366, 738-740, doi: $10.1038 / 366738 \mathrm{a} 0$.
Lode T. 2008. Kin recognition versus familiarity in a solitary mustelid, the European polecat Mustela putorius. Comptes Rendus Biologies 331, 248-254, doi: 10.1016/j. crvi.2007.12.006.

Loeng H. 1991. Features of the physical oceanographic conditions of the Barents Sea. Polar Research 10, 5-18, doi: 10.3402/polar.v10il.6723.

Lone K., Aars J. \& Ims R.A. 2013. Site fidelity of Svalbard polar bears revealed by mark-recapture positions. Polar Biology 36, 27-39, doi: 10.1007/s00300-012-1235-y.

Lone K., Merkel B., Lydersen C., Kovacs K.M. \& Aars J. 2018. Sea ice resource selection models for polar bears in the Barents Sea subpopulation. Ecography 41, 567-578, doi: 10.1111 /ecog.03020.

Loset S. \& Carstens T. 1996. Sea ice and iceberg observations in the western Barents Sea in 1987. Cold Regions Science and Technology 24, 323-340, doi: 10.1016/0165-232X(95)00029-B.

Lydersen C. 1998. Status and biology of ringed seals (Phoca hispida) in Svalbard. NAMMCO Scientific Publications 1, 46-62, doi: 10.7557/3.2980.

Maher C.R. 2009. Genetic relatedness and space use in a behaviorally flexible species of marmot, the woodchuck (Marmota monax). Behavioral Ecology and Sociobiology 63, 857-868, doi: 10.1007/s00265-009-0726-5.

Mateo J.M. 2002. Kin-recognition abilities and nepotism as a function of sociality. Proceedings of the Royal Society of London B 269, 721-727, doi: 10.1098/rspb.2001.1947.

Mauritzen M., Andrew E. \& Wiig O. 2001. Space-use strategies of female polar bears in a dynamic sea ice habitat. Canadian Journal of Zoology 79, 1704-1713, doi: 10.1139/ cjz-79-9-1704.

Messier F., Taylor M.K. \& Ramsay M.A. 1992. Seasonal activity patterns of female polar bears (Ursus maritimus) in the Canadian Arctic as revealed by satellite telemetry. Journal of Zoology 226, 219-229, doi: 10.1111/j.1469-7998.1992. tb03835.x.

Mohr C.O. 1947. Table of equivalent populations of North American small mammals. The American Midland Naturalist 37, 223-249, doi: 10.2307/2421652.

Moyer M.A., McCown J.W., Eason T.H. \& Oli M.K. 2006. Does genetic relatedness influence space use pattern? A test on florida black bears. Journal of Mammalogy 87, 255-261, doi: 10.1644/05-mamm-a-192rl.1.

Muckenhuber S., Nilsen F., Korosov A. \& Sandven S. 2016. Sea ice cover in Isfjorden and Hornsund, Svalbard (2000-2014) from remote sensing data. Cryosphere 10, 149-158, doi: 10.5194/tc-10-149-2016.

Obbard M.E., Debruyn T.D., Thiemann G.W. \& Peacock E. 2010. Polar bear conservation 2005-2009. In M.E. Obbard et al. (eds.): Polar bears: proceedings of the 15th working meeting of the IUCN/SSC Polar Bear Specialist Group, Copenhagen, Denmark, 29 June - 3 July 2009. Pp. 157-163. Gland: International Union for Conservation of Nature and Natural Resources.

Odden M., Ims R.A., Stoen O.G., Swenson J.E. \& Andreassen H.P. 2014. Bears are simply voles writ large: social structure determines the mechanisms of intrinsic population regulation in mammals. Oecologia 175, 1-10, doi: 10.1007/ s00442-014-2892-z. 
Pagano A.M., Atwood T.C., Durner G.M., Williams T.M. 2020. The seasonal energetic landscape of an apex marine carnivore, the polar bear. Ecology 101, e02959, doi: 10.1002/ ecy.2959.

Perrin N. \& Mazalov V. 1999. Dispersal and inbreeding avoidance. The American Naturalist 154, 282-292, doi: $10.1086 / 303236$.

Piechura J. \& Walczowski W. 2009. Warming of the West Spitsbergen Current and sea ice north of Svalbard. Oceanologia 51, 147-164, doi: 10.5697/oc.51-2.147.

Pope T.R. 2000. Reproductive success increases with degree of kinship in cooperative coalitions of female red howler monkeys (Alouatta seniculus). Behavioral Ecology and Sociobiology 48, 253-267, doi: 10.1007/s002650000236.

Prop J., Aars J., Bardsen B.J., Hanssen S.A., Bech C., Bourgeon S., De Fouw J., Gabrielsen G.W., Lang J., Noreen E., Oudman T., Sittler B., Stempniewicz L., Tombre I., Wolters E. \& Moe B. 2015. Climate change and the increasing impact of polar bears on bird populations. Frontiers in Ecology and Evolution 3, article no. 33, doi: $10.3389 /$ fevo.2015.00033.

Przybylak R., Arazny A., Nordli O., Finkelnburg R., Kejna M., Budzik T., Migala K., Sikora S., Puczko D., Rymer K. \& Rachlewicz G. 2014. Spatial distribution of air temperature on Svalbard during 1 year with campaign measurements. International Journal of Climatology 34, 3702-3719, doi: 10.1002/joc.3937.

R Core Team 2017. R: a language and environment for statistical computing. Vienna: R Foundation for Statistical Computing.

Rode K.D., Regehr E.V., Douglas D.C., Durner G., Derocher A.E., Thiemann G.W. \& Budge S.M. 2014. Variation in the response of an Arctic top predator experiencing habitat loss: feeding and reproductive ecology of two polar bear populations. Global Change Biology 20, 76-88, doi: $10.1111 /$ gcb.12339.

Rogers L.L. 1987. Factors influencing dispersal in the black bear. In B.D. Chepko-Sade \& Z.T. Halpin (eds.): Mammalian dispersal patterns: the effects of social structure on population genetics. Pp. 75-84. Chicago, IL: University of Chicago Press.

Rydell J. 1989. Site fidelity in the northern bat (Eptesicus nilssoni) during pregnancy and lactation. Journal of Mammalogy 70, 614-617, doi: 10.2307/1381433.

Silk J.B. 2007. The adaptive value of sociality in mammalian groups. Philosophical Transactions of the Royal Society B 362, 539-559, doi: 10.1098/rstb.2006.1994.

Smith J.E. 2014. Hamilton's legacy: kinship, cooperation and social tolerance in mammalian groups. Animal Behaviour 92, 291-304, doi: 10.1016/j.anbehav.2014.02.029.

Stirling I. 1974. Midsummer observations on the behavior of wild polar bears (Ursus maritimus). Canadian Journal of Zoology 52, 1191-1198, doi: 10.1139/z74-157.
Stirling I., Spencer C. \& Andriashek D. 1989. Immobilization of polar bears (Ursus maritimus) with Telazol in the Canadian Arctic. Journal of Wildlife Diseases 25, 159-168, doi: 10.7589/0090-3558-25.2.159.

Stoen O.G., Bellemain E., Saebo S. \& Swenson J.E. 2005. Kin-related spatial structure in brown bears Ursus arctos. Behavioral Ecology and Sociobiology 59, 191-197, doi: 10.1007/s00265-005-0024-9.

Stone I.R. \& Derocher A.E. 2007. An incident of polar bear infanticide and cannibalism on Phippsoya, Svalbard. Polar Record 43, 171-173, doi: 10.1017/S0032247407246170.

Switzer P.V. 1993. Site fidelity in predictable and unpredictable habitats. Evolutionary Ecology 7, 533-555, doi: 10.1007/BF01237820.

Tang-Martinez Z. 2001. The mechanisms of kin discrimination and the evolution of kin recognition in vertebrates: a critical re-evaluation. Behavioural Processes 53, 21-40, doi: 10.1016/S0376-6357(00)00148-0.

Taylor M.K., Akeeagok S., Andriashek D., Barbour W., Born E.W., Calvert W., Cluff H.D., Ferguson S., Laake J., Rosing-Asvid A., Stirling I. \& Messier F. 2001. Delineating Canadian and Greenland polar bear (Ursus maritimus) populations by cluster analysis of movements. Canadian Journal of Zoology 79, 690-709, doi: 10.1139/cjz-79-4-690.

Waser P.M., Jones W.T., Philopatry N. \& Jones W.T. 1983. Natal philopatry among solitary mammals. Quartely Review of Biology 58, 355-390, doi: 10.1086/413385.

Wiig O. 1995. Distribution of polar bears (Ursus maritimus) in the Svalbard area. Journal of Zoology 237, 515-529, doi: 10.1111/j.1469-7998.1995.tb05012.x.

Yu L., Li Q., Ryder O.A. \& Zhang Y. 2004. Phylogeny of the bears (Ursidae) based on nuclear and mitochondrial genes. Molecular Phylogenetics and Evolution 32, 480-494, doi: 10.1016/j.ympev.2004.02.015.

Zedrosser A., Stoen O.G., Saebo S. \& Swenson J.E. 2007. Should I stay or should I go? Natal dispersal in the brown bear. Animal Behaviour 74, 369-376, doi: 10.1016/j. anbehav.2006.09.015

Zeyl E., Aars J., Ehrich D., Bachmann L. \& Wiig O. 2009. The mating system of polar bears: a genetic approach. Canadian Journal of Zoology 87, 1195-1209, doi: 10.1139/Z09-107.

Zeyl E., Aars J., Ehrich D. \& Wiig O. 2009. Families in space: relatedness in the Barents Sea population of polar bears (Ursus maritimus). Molecular Ecology 18, 735-749, doi: 10.1111/j.1365-294X.2008.04049.x.

Zeyl E., Ehrich D., Aars J., Bachmann L. \& Wiig O. 2010. Denning-area fidelity and mitochondrial DNA diversity of female polar bears (Ursus maritimus) in the Barents Sea. Canadian Journal of Zoology 88, 1139-1148, doi: 10.1139/ Z10-078. 